\title{
Henry James, Fredric Jameson, and the Social Art of Sculpture
}

\section{Citation}

Alworth, David J. 2015. "Henry James, Fredric Jameson, and the Social Art of Sculpture." The Henry James Review 36 (3): 212-225. doi:10.1353/hjr.2015.0019. http://dx.doi.org/10.1353/ hjr.2015.0019.

\section{Published Version}

doi:10.1353/hjr.2015.0019

\section{Permanent link}

http://nrs.harvard.edu/urn-3:HUL.InstRepos:29058541

\section{Terms of Use}

This article was downloaded from Harvard University's DASH repository, and is made available under the terms and conditions applicable to Other Posted Material, as set forth at http:// nrs.harvard.edu/urn-3:HUL.InstRepos:dash.current.terms-of-use\#LAA

\section{Share Your Story}

The Harvard community has made this article openly available.

Please share how this access benefits you. Submit a story.

Accessibility 


\title{
Henry James, Fredric Jameson, and the Social Art of Sculpture
}

\author{
By David J. Alworth, \\ Harvard University
}

In 1915, writing in his capacity as chairman of the American Volunteer Motor Ambulance Corps, Henry James began an article on Fredrick MacMonnies. The chairman wanted to express his gratitude to the sculptor, who had made a monetary donation to the Corps, and the arrival of a catalogue, documenting the exhibition from whose proceeds the donation had been drawn, was the impetus for the article. "I lose myself in the perusal of the catalogue," James confessed, "for a just appreciation of the artist's activity and generosity, and have therewith the delightful sense of a confidence excited and an experience renewed" (HJC 3). This sense was prompted by memory: "My recollection is a matter of days, old Paris days, considerably past, when I envied the sculptor, more than I can say, his ideas and his results, his inspirations and his problems, his questions and his company." Suddenly made palpable by the look and feel of the catalogue, James's envy was both historical and aesthetic. Just as he longed for a "golden age of innocence," before the onset of the war, indeed before the arrival of "a smoke-smothered world, where every light save that of battle burn[ed] so low as scarce to be discernable," so too he could see, through the green eyes of his younger self, "the range and variety of the artist's power of projection." While James went on to praise MacMonnies's sculptural achievements- "ex-President Roosevelt as a Colonel of Rough Riders," "a concentrated Shakespeare," "that breathing Bacchante of the Luxembourg Museum" - he never completed the article. Its last words, a note to himself that employs a sculptural trope, indicate James's intention to "make direct reference to the general cast of [his] whole remembrance," but a blank space in the manuscript follows James's imperative to let that remembrance "somehow serve" (4). This manuscript, then, suggests that sculpture was a forceful instigation for the novelist, both early and late in his career, yet it is tantalizingly inconclusive on the nature of that instigation: on the question of how the theory and practice of sculpture provoked the art of fiction. 
The answer must be manifold, for it was not any one element of MacMonnies's life and work, but the whole panoply of his "ideas," "results," "inspirations," "problems," "questions," and "company" that stirred the novelist's profound yet nearly inarticulate desire. Although, as Wallace Stevens says, the "interchange . . . between one art and another" always involves an elusive relay- "migratory passings to and fro, quickenings, Promethean liberations and discoveries" (169)—it seems clear that James was compelled equally by the theory, practice, and social context of sculpture, an art that appears throughout his writings, including his fictions, critical pieces, travelogues, and letters. In what follows, I examine a selection of such writings, my emphasis falling on what I call the Gloriani trilogy (Roderick Hudson [1875], The Ambassadors [1903], and "The Velvet Glove" [1909]), in order to make the case that sculpture was keenly important, indeed central, to James's literary and intellectual practice. Although several generations of scholars have attended to James's life-long interest in the visual arts, his treatment of sculpture in particular remains relatively underappreciated. ${ }^{1}$ I argue, however, that comprehending the art of fiction, as James both practiced and theorized it, requires grasping the contours of his multifaceted sculptural desire. To develop this argument, I turn to the writings of Fredric Jameson. Over the course of his career, Jameson has repeatedly addressed James, but he has not offered much in the way of commentary on sculpture as such. And yet, as in the case of the novelist, sculpture plays a subtly significant role in Jameson's work, particularly in the opening gambit of Postmodernism, or, The Cultural Logic of Late Capitalism (1991). To pair James and Jameson in this way is, of course, to violate Jameson's own "periodizing hypothesis," wherein "postmodernism" names a "radical break or coupure" from the modern, but such a violation will justify itself, I hope, by eventuating in a new sense of the novelist, the theorist, and the link between them $(3,1)$. Schematically put, just as it accounts for James's engagement with sculpture in Jamesonian terms, so too it reveals Jameson to be the sort of relational artist that James imagined.

Over nearly five decades, since the 1971 publication of Marxism and Form, a pattern has emerged in Jameson's thinking about James. His discussions of the novelist, irrespective of the argument in which they reside, almost always address the technique and concept of point of view. He claims in Marxism and Form, for instance, that point of view is "the basic category of novelistic practice" for James "because it corresponded to our lived experience, in which we always remain in situation, seeing life from the relatively restricted vision of our own monad" (355). Had Jameson's James been a sculptor himself, then, he would have modeled figures that resemble Derwent Wood's clay bust of the novelist, with its piercing eyeballs couched inside two creased and wrinkled sockets, bespeaking the particularity of individual vision (see Fig. 1). But when James's actual face was cast in plaster, either before or just after death, his eyes were covered in protective gauze (Fig. 2). The exact timing of the cast is unclear. ${ }^{2}$ As a life mask, made from a living subject, it is a poor effigy for a master of point of view; the gauze technique would produce a better result for a master of "pastiche," since the latter, as Jameson contends in Postmodernism, constitutes "blank parody, a statue with blind eyeballs" (17). As a death mask, though, it is more successful: it might be understood to memorialize what Jameson, in The Political Unconscious (1981), calls the novelist's "genuinely historical act" of transforming point of view "into the most fundamental of narrative categories" (221). By the time of James's death, as 


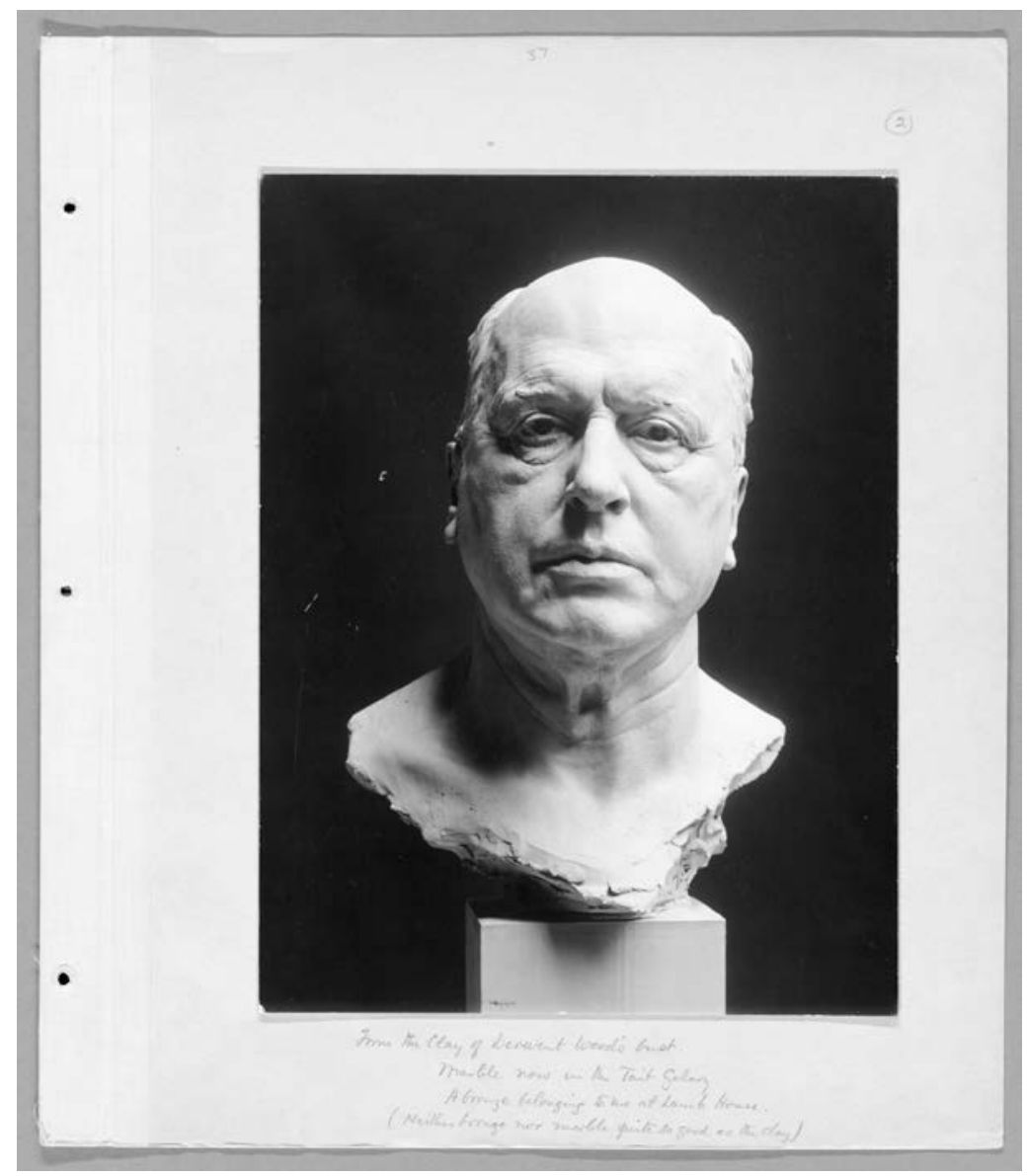

Figure 1. Derwent Wood's bust of Henry James, clay, 1913. Correspondence and Journals of Henry James Jr. and Other Family Papers, 1855-1916 (MS Am 1094), Houghton Library, Harvard University.

Jameson asserts in The Modernist Papers (2007), this act was already perceived as historical, even passé, by members of the literary avant-garde, which partly explains why it took until the 1950s for James (like Melville) to win full recognition as a great American novelist. "I am tempted to say," writes Jameson of the Eumeaus portion of Ulysses, "that this chapter really constitutes Joyce's attempt at a parody or pastiche of a writer he had no particular sympathy or respect for, namely Henry James" (149).

The theorist's discussion of this attempt, regardless of whether Ulysses registers as parodic or merely imitative, ultimately supports his assessment, in Antinomies, of James's outsize influence on modern fiction: his status as "the fundamental theoretician" of "English-language narratology" whose "critical and theoretical reflections on the art of the novel . . have been as fundamental for narrative analysis in modern times as Aristotle's for the classical world" $(21,181)$. In fact, Jameson frequently casts James as a practicing narratologist—each of whose fictions "can be seen as a laboratory experiment which poses a distinct form-problem in its own right" (156)—rather than a novelist. "I think it might clarify our view of his work," the theorist suggests 


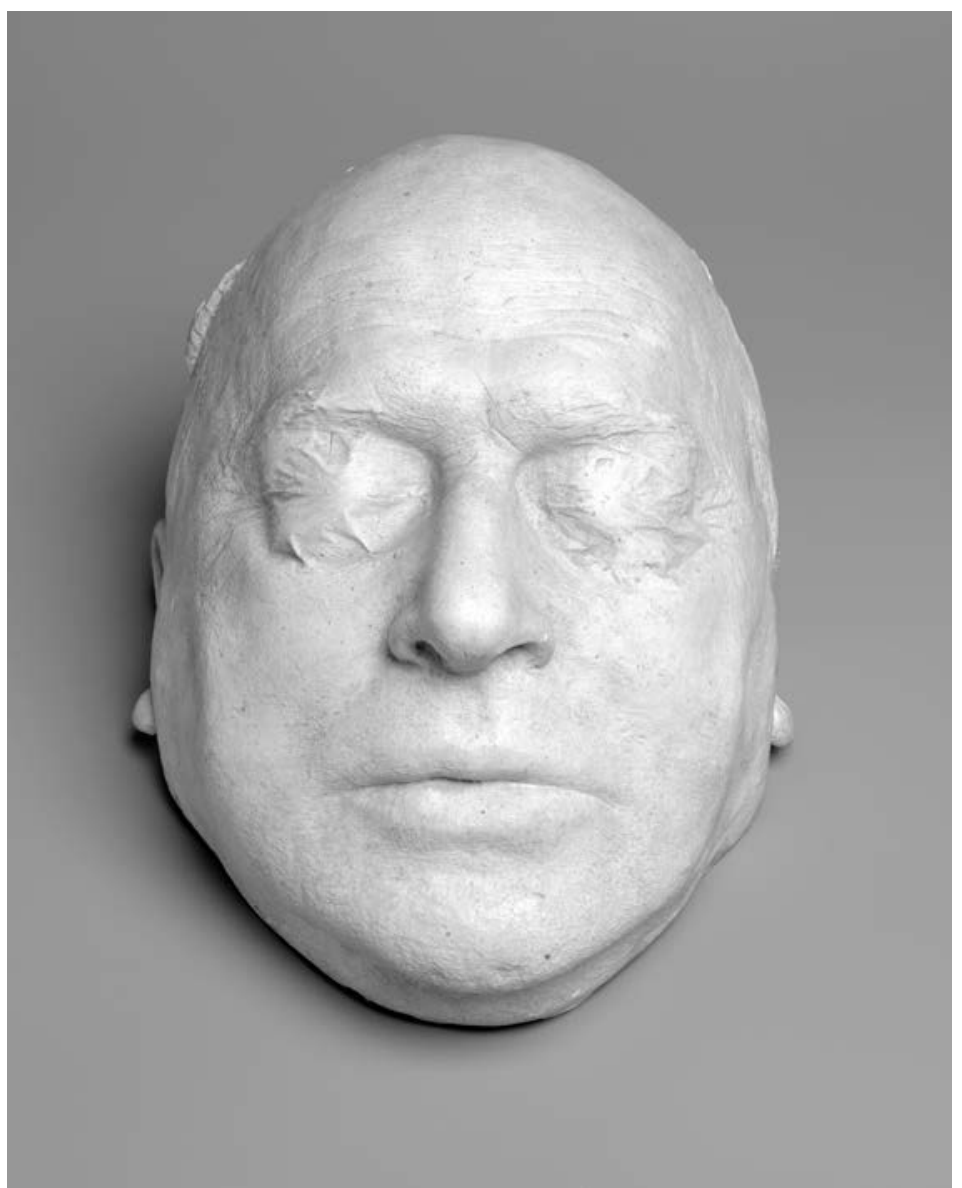

Figure 2. Henry James Life Mask, undated, 1 cast (sculpture); plaster; $23 \times 20$ × $18 \mathrm{~cm}$. *45Z-1a, Houghton Library, Harvard University.

in Antinomies, "if we step back to recognize that he was essentially a writer of short stories or of their longer cousin, the art-novella" (181-82). With this suggestion, Jameson urges us to acknowledge James's "achievements" within two literary genres that are "both quite different in their requirements than the novel itself," but he also reminds us that James regularly addressed the "requirements" of different media in his numerous fictions about the fine arts, especially those fictions that are indebted to an older Renaissance tradition whose most famous representative is Boccaccio (182). ${ }^{4}$ And insofar as Jameson identifies the dialectic whereby James sought to refine the art of fiction, in both theory and practice, by dwelling on the theories and practices of other arts, he echoes Hugh Kenner, whose Pound Era (1971) appeared in the same year as Marxism and Form. "Henry James," Kenner writes, "was mesmerized by 'artists"” and inspired by their vocation: "James made not stories but 'things,' and did not write them but 'did' them. . . . He was helped by conceiving that he did not tell but make: making objects, substantial as statues and heavy framed pictures are substantial" (27). 
In Antinomies, then, Jameson channels Kenner's critical spirit when he defines James as a "professional writer" who sought, simultaneously, to elevate fiction to the status of fine art and to align the literary artist with what Kenner terms "a caste of men who in places called studios, with brush, pigment, sponge, and varnishbottle, practiced a mystery which entails a gift they call 'rightness of touch'" (182, 27). ${ }^{5}$ Moreover, even though Jameson never quite reiterates Kenner's suggestion that James wanted fiction to be sculptural- "to partake of the enigmatic silence of objects" and to function as though it "existed in three-dimensional space" (27)—the theorist nevertheless provides, in his account of sculpture in Postmodernism, an apt analytical model for appreciating James's engagement with the art of the chisel and the mold. Like Kenner, Jameson emphasizes both technique ("rightness of touch") and technician ("caste of men"): he insists that sculpture must be understood as both an art and a social practice. This insistence becomes especially forceful in his brief but telling analysis of Duane Hanson, a sculptor known for highly realistic casts of human figures in polyester, resin, Bondo, fiberglass, and other materials (Fig. 3). The plastic arts always hover in the background of Jameson's argument, because his "conception of postmodernism" was first sparked by Robert Venturi's critique "of the high-modernist transformation of the building into a virtual sculpture," but the analysis of Hanson brings these arts to the fore (PO 2).

Framed as an effort to anatomize "that euphoria or those intensities which seem so often to characterize the newer cultural experience," this analysis eventually takes the form of a direct address to the reader (32). "Your moment of doubt and hesitation as to the breath and warmth of these figures," Jameson writes of Hanson's Museum Guard and Tourists II, "tends to return upon the real human beings moving about you in the museum and to transform them also for the briefest instant into so many dead and flesh-colored simulacra in their own right" $(32,34)$. Hanson's extreme anthropomorphism, in other words, produces a double ambiguity within the social site of display: at the moment we mistake sculptures for museumgoers, we also mistake museumgoers for inanimate things. "The world thereby momentarily loses its depth," Jameson concludes, "and threatens to become a glossy skin, a stereoscopic illusion, a rush of filmic images without density" (34). Hanson's work, in this sense, discloses what Jameson calls the "new depthlessness" of postmodern culture, by which he means that such sculpture simultaneously precipitates and registers a key element of cultural experience within a specific historical period, beginning in "the 1950s or the early 1960s" (1). Nevertheless, in exploiting the unstable boundary between thing and person, Hanson inhabits a rich cultural tradition that extends as far back as the Pygmalion myth and that includes James, whose own writings on sculpture (as on other material things) often dramatize ontological indeterminacy. ${ }^{6}$ "The statues," muses the narrator of "The Last of the Valerii" (1874), "used to stand in the perpetual twilight like conscious things, brooding on their long observations. I used to linger near them, half expecting they would speak and tell me their stony secrets-whisper hoarsely the whereabouts of their mouldering fellows, still unrecovered from the soil" (CS1 802). Likewise, as the narrator of "The Solution" (1889) recounts his time in Rome, he fondly remembers how "the old statues in the villas and galleries became one's personal friends" (CS2 665).

To imagine statues as confidantes or friends is to render sculpture's ontological indeterminacy as a social phenomenon. Like Jameson, who focuses on "your" 


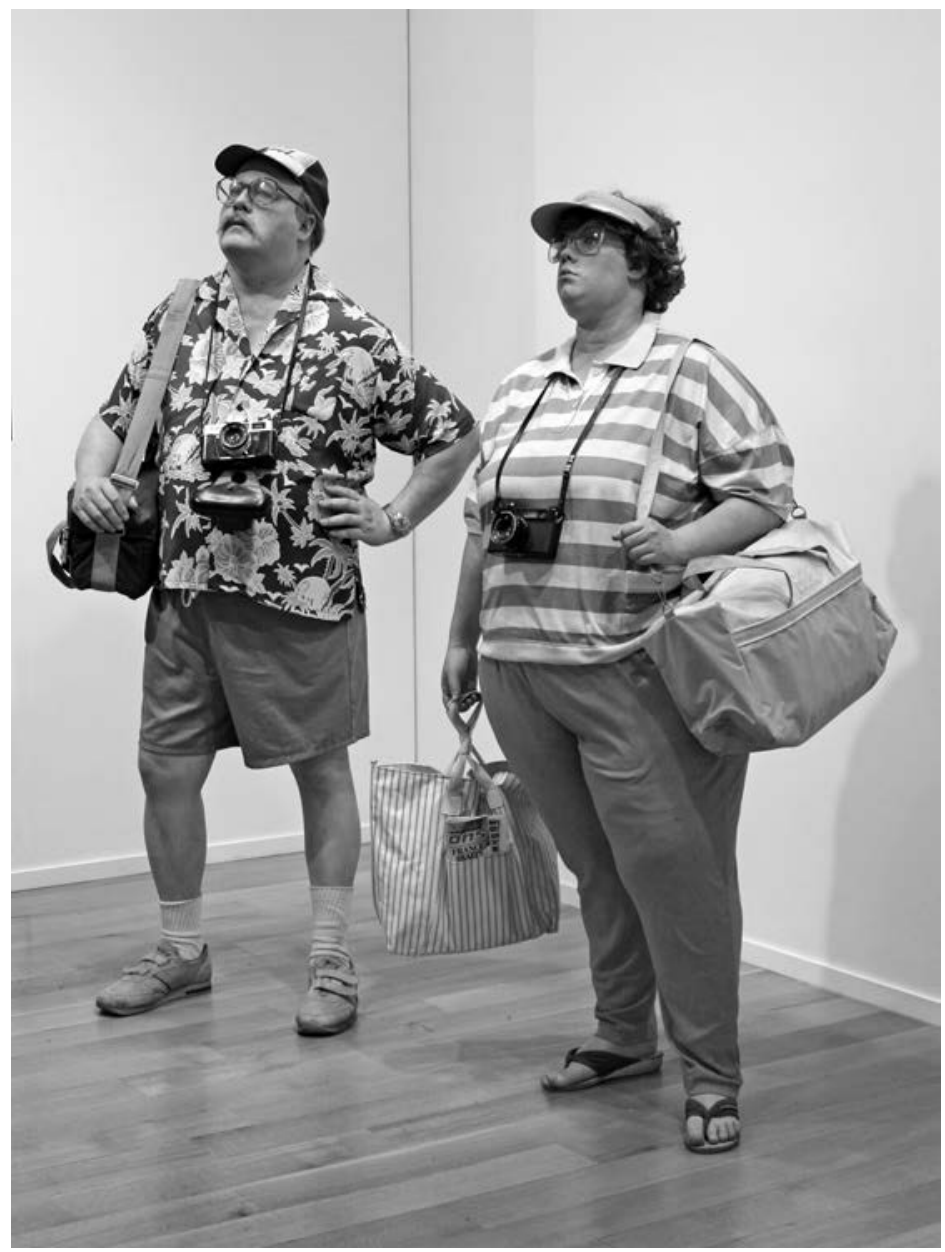

Figure 3. Duane Hanson, Tourists II (1988). Courtesy Van de Weghe Fine Art, New York. Art (C) The Estate of Duane Hanson/Licensed by VAGA, New York, NY.

experience of seeing a Hanson amid other museumgoers, James often addresses sociality in his writings on sculpture and other arts, precisely because he considered art an inextricably social affair, one in which, as Susan Griffin puts it, "artist, critic, and audience together create the work" (PE 8). Take, for instance, William Wetmore Story and His Friends (1903), a two-volume biography whose title alone stresses the social life of art. Although James was ambivalent about Story's work and reluctant to write about him, the biography is nevertheless a richly suggestive text. As Sheila Teahan explains, "Story plays an overdetermined role in the Jamesian imaginary: he is at once a figure for the nineteenth-century American artist abroad, a place-holder for authorial anxieties associated in particular with Hawthorne, and the occasion for James's reflection on questions of representation" (246).

At times, such reflection takes the form of a panaesthetic meditation: ${ }^{7}$ 
It was not that [Story] failed to grasp the plastic, but much rather that he saw it everywhere, and that, wherever seen, it tempted and challenged him. It tempted him perpetually in the form of verse, and he is singular in having apparently, in respect to some alternatives, never really made up his mind. He was as addicted to poetry as if he had never dreamed of a statue, and as addicted to statues as if he were unable to turn a verse. Add to this that he constantly overflowed, by spoken and by written talk, into an extremely various criticism, and we see that, if the approach to final form be through concentration, he was not concentrated. If a sculpture be a thing of supreme intimacy, he was not supremely intimate. He had, in a word, too many friends for any one of them ever to have succeeded in establishing absolute rights. It was, aesthetically speaking, a wonderful all-round sociability. (WWS 84)

Replete with backhanded compliments, this passage conveys the ambiguity that appears throughout James's treatment of his subject. " [T] here is nothing in the man himself to write about," he complained to William Dean Howells in 1902. "There is nothing for me but to do a tour de force, or try to-leave poor W.W.S. out, practically, and make a little volume on the old Roman, Americo-Roman, Hawthornesque, and other bygone days (HJL 224-25). But such ambiguity seems to have been there from the beginning-ever since James, as a young American writer in Rome, first visited Story at his quarters in the magisterial Palazzo Barberini. ${ }^{9}$ On the one hand, as James wrote to his mother in January of 1873 , he found Story "friendly, humorous, and clever," while on the other hand, as he wrote to Charles Eliot Norton two months later, he considered the sculptor to be "a case of preposterous pretention [sic]" whose "cleverness" hardly warranted "the world's good nature to him" (CL 198, 251).

His decision to situate Story among "friends," however, was not just a way to expand the cast of the biography to include more interesting subjects. It was also an effort to present the sculptor as a social actor. Just as James acknowledged and valued MacMonnies's “company” (as well as his socially minded gift to the Ambulance Corps), so too he praised Story's “wonderful all-round sociability” (WWS 84). Indeed, the account of Story's interartistic sensibility, poised between the plastic and the poetic, quickly becomes a report on his extroverted volubility: his "many friends" and his tendency to overflow with "spoken and written talk." While James equivocated on Story's sculpture, which he called both "clever" and "fatally unsimple" in a March 1873 letter to Grace Norton, he seemed to admire the sculptor's social performance (CL 233). As in the case of MacMonnies, such admiration might appear tinged with envy, especially if we accept Jameson's characterization of James, in Antinomies, as "a minor character in real life, a listener and observer, a voyeur and a gossip, the eager recipient of hearsay and tall tales of all kinds (preferably usable ones!)" (101). But I want to suggest that this admiration, however qualified, has less to do with envy than with the fact that, by 1903, James had come to regard sculpture as a kind of performance art and to see the sculptor as a kind of performance artist, whose "fathomless medium" is neither marble nor clay but "the displayed tangle of human relations" within "the contemporary social salad" (NO2 134, AN 63, 91). ${ }^{10}$ This is a way of suggesting that, late in his career, James construed the figure of the sculptor as Jameson construes Hanson. Rather than treating Hanson's work to an intricate 
Marxist-formalist analysis-to what The Political Unconscious calls the "essentially allegorical act" of "rewriting a given text in terms of a particular interpretive master code" (10)-Jameson simply includes illustrations of Museum Guard and Tourists $I I$, as if to say, when it comes to aesthetic form, you can see for yourself, but what really matters here is social effect: that startling moment when art transforms your perception of other subjects.

In this sense, even though Hanson is most obviously a social realist and a pop artist, Jameson's analysis places him on a continuum that runs from minimalism to what has come to be called "relational art." All the work on this continuum, according to predominant critical accounts, involves an element of performance. For instance, in "Art and Objecthood" (1967)—the negative yet foundational treatment of minimalism that Jameson himself addresses in Antinomies-Michael Fried argues that "minimal" or "literal" art is "fundamentally theatrical" because "it is concerned with the actual circumstances" of display and reception, within which it relies on a "latent or hidden . . . anthropomorphism" that "extorts" participation from the beholder $(157,153,155)$. Encountering such art "is not," Fried contends, "entirely unlike being distanced, or crowded, by the silent presence of another person; the experience of coming upon literalist objects unexpectedly_for example, in somewhat darkened rooms-can be strongly, if momentarily, disquieting in just this way" (155). Jameson describes Hanson's extreme anthropomorphism in similar terms, but he envisions the relation between art object and beholding subject as part of a triangular structure that also includes other beholders. And to the degree that the theorist emphasizes the social dynamics of aesthetic reception-how art mediates "your" interaction with "the other human beings moving about you"- - he positions Hanson's work as a precursor to contemporary relational art, which is art that, according to Nicholas Bourriaud, "take[s] as [its] theoretical and practical point of departure the whole of human relations and their social context" (113). Instead of creating symbolic objects for individual consumption, Bourriaud contends, relational artists, such as Rirkrit Tirivanija, Liam Gillik, and Christine Hill, orchestrate social interactions (not unlike Happenings or Fluxus events) that capacitate beholders as performers. ${ }^{11}$ When Tirivanija cooks and serves Thai cuisine to museum patrons and staff, for instance, he seeks not merely to arrange a convivial encounter but to "produce a model of sociability" within the gallery space $(17,109)$.

By the time James set out to write William Wetmore Story and His Friends, he was compelled no less than Bourriaud (and Jameson) by the conception of the artist, specifically the sculptor, as a modeler of social forms. This conception appears in Story and elsewhere but attains fullest expression in The Ambassadors, which was finally brought out by Harper \& Brothers in the same year as the biography. ${ }^{12} \mathrm{~A}$ central figure in the Parisian art world, the character of Gloriani represents, to adapt Jonathan Freedman, "James's prototype for the (visual) artist" as relational artist, who is, above all, an orchestrator or facilitator of social interactions rather than a creator of physical objects (141). But, as they say in the design world, this prototype emerged iteratively over the course of three fictions: Roderick Hudson, The Ambassadors, and "The Velvet Glove." The latter takes place for the most part in Gloriani's garden-which is also the site of Strether's "irrepressible outbreak" in The Ambassadors (AN 307)—where the majestic artist is not making objects but hosting yet another lavish affair, his "studio" functioning as a social venue and his magnanimous 
presence enabling guests from different social strata to interact with ease. "He was all right where he was," the narrator says of protagonist John Berridge; "the great Gloriani somehow made that law; his house, with his supreme artistic position, was good enough for anyone, and tonight in especial there were charming people, more charming than our friend could recall from any other scene" (CS3 736). Indeed, by means of his superb "artistic sensibility," Gloriani projects "a large, clear, common ether, an element all uplifted and rare, of which they could equally partake" (741). When Strether himself partakes of this ether, or inhabits this august aura, he learns how it feels to be suspended in Gloriani's presence-to be, as the narrator of The Ambassadors puts it, "held by the sculptor's eyes” (NO2 148).

But Gloriani is not nearly so august in Roderick Hudson. In this novel, he has not yet reached the Olympian heights that he will attain in the later fictions. He is talented and successful, but his statues are "florid and meretricious . . like magnified goldsmith's work" (NO1 237). Similar to Story, who likely provided some inspiration for the character, he is "a great talker, and a very picturesque one," but "[h]e ha[s] a definite, practical scheme of art," a scheme that emphasizes marketability (236). He is skilled, but not preternaturally gifted; it took "fifteen years of indefatigable exercise" to bring his art "to perfection." And, perhaps most tellingly, he fails to enchant our protagonist as he enchants both Strether and Berridge: "Gloriani's an ass!" asserts Roderick (262). So what accounts for the change? Why does James transform a rather pedestrian character-an artist, in a body of fiction replete with artists, who makes "a very pretty trade in sculpture of the ornamental and fantastic sort" (236)—into a "dazzling prodigy of type," whose "penetrating radiance," "illustrious spirit," and "personal lustre" give him the veneer of a "glossy male tiger, magnificently marked"? (NO2 148-49, 164). Critics have offered two good answers. Viola Hopkins argues that the change corresponds to (and corroborates) the drastic shift in James's aesthetic taste between the 1870s and the early 1900s (see Hopkins). At first, as Peter Brooks has documented in detail, James rejected the "emblematic works of nascent modernism” (4)—Whistler's Nocturnes, Monet's Impressions, what James himself called "Barye's businesslike little lions" (PE 15)—but, by the turn of the century, he had come to embrace Whistler, a possible model for Gloriani, and to see Impressionism as a major movement. ${ }^{13}$ No less important to the change in Gloriani, though, was James's erotic liaison with young sculptor Hendrik Andersen, whom he met in Rome in the 1890 s while conducting research for the Story biography. ${ }^{14}$ Andersen, as Ross Posnock suggests, helped to inspire the open eroticism of The Ambassadors, the figure of the "glossy male tiger" in particular (215).

Notwithstanding the power of these answers, I want to propose that the change in Gloriani registers something else: James's own formation of a relational aesthetic. If, as Brad Evans has recently argued, "[ $\mathrm{t}]$ he relation in late James is a constant," then this constant emerged partly through sustained engagement with the art of sculpturean art that, as Jameson implies in his reading of Hanson, dramatizes relationality with particular force (4). Consider, for example, the moment in The American Scene (1907) when James happens upon a monument in Washington Square Park: "that lamentable little Arch of Triumph" whose spandrel figures are MacMonnies's work. While our "restless analyst" finds several reasons to be cranky at this moment, above all because his childhood home has been razed, he deems the statue itself "lamentable because of its poor and lonely and unsupported and unaffiliated state" (CTW 430). 
Unlike the statutes in "The Last of the Valerii," the Arch has no "fellows," so it is a "melancholy monument" to which James himself "could make no terms at all." And yet, no matter how it appears to James's eyes, the Arch is widely affiliated: it was created, like much sculpture, by multiple makers as part of a social process. ${ }^{15}$ Indeed, as Hawthorne describes in The Marble Faun (1860), a novel that James had in mind as he wrote Roderick Hudson, the art of sculpture often proceeds through "stages of advancement," beginning with "the intimate production of the sculptor himself, moulded throughout with his loving hands," and followed by "the process of actually chiseling the marble, with which (as it is not quite satisfactory to think) a sculptor, in these days, has very little to do" (948). ${ }^{16}$ Moreover, in the case of the Arch, its many other affiliations and relations can be schematized spatially: it points down to the site that it marks as significant, up to the ideals of democracy and valor represented by George Washington, and laterally through its opening to what James himself calls "the higher latitudes" of midtown Manhattan and the lower ones of Greenwich Village (CTW 430). ${ }^{17}$

When it comes to the Gloriani trilogy, however, the key sculptural relation is that of replication. If, in the most conventional sense, a replica is a "copy or duplicate of a work of art," especially "a copy made by the original artist," then the act of replication always involves an interplay between sameness and difference (OED). This interplay is especially complex in the case of sculpture (as in the case of printmaking) because certain practices, such as casting and the type of indirect carving lamented by Hawthorne, strive to effect sameness in difference. In both practices, the sculptor produces a model, usually out of clay, wax, or plaster, that forms the basis for the production of multiple, different sculptures that are nonetheless the same work of art. The two dozen or so casts of The Thinker, for example, share a common identity; Rodin's sculpture, as Gérard Genette puts it, “immanates in this particular cast or $(\mathrm{vel})$ in another, the assumption being that, when you have seen one, you have seen them all" (172). James, for his part, explores the paradox of sameness in difference throughout Roderick Hudson, whose eponymous character is not only a gifted young sculptor but also, "like most men with a turn for the plastic arts," "an excellent mimic" (NO1 183). Even as Roderick makes objects, portrait busts, that are replicated in the conventional sense (as James's own bust was replicated in both marble and bronze), so too he replicates, via performative action, "the accent and attitude of a pompous country lawyer." But action is not the only mode of replication in the Gloriani trilogy; it appears in dialogue and description, as well. When, in the climactic final scene of "The Velvet Glove," Berridge blurts out his advice to the Princess- “Only live. Only be" (CS3 758)—he replicates Strether's "irrepressible outburst" to Little Bilham: "Live all you can; it's a mistake not to" (NO2 162). And when James begins the short story with an introduction to his characters' thoughts, he employs a syntax of replication- "He wondered, the splendid young man, he wondered awfully, he wondered (it was unmistakable) quite nervously, he wondered, to John's ardent and acute imagination, quite beautifully" (CS3 733) — that presents the same action, the same verb, successively inflected by different adverbs.

Within Roderick Hudson, moreover, replication is a characterological phenomenon. In addition to thematizing resemblance through its many discussions of sculptural busts and portraiture, the novel, as Sharon Cameron has observed, relies on a character system wherein different characters seem to be "reproductions of each 
other": individuals who are not fully individuated (46). Thus, we might say that along with likening character to sculpture- "He never understood me," cries Roderick, after smashing the bust of his employer; "we're made of different clay" (NO1 195)_James plays on the paradox of sameness in difference to render relations among characters as sculptural replications. His point, as Cameron suggests, is to convince us that "relations stop nowhere" (AN 5). "[I]t is in terms of the inadequate differentiation among ostensibly discrete characters," she argues, "that continuousness in the novel manifests itself" (48-49). Such continuousness is both a major theme and a key structural feature of the Gloriani trilogy. Insofar as The Ambassadors, for instance, constitutes what Cameron calls “James's overt, if silent, rewriting of Roderick Hudson," it not only continues Gloriani's story but also registers as a replica, cast in the finer medium of James's late prose, of the novel in which he first appears. And wherever this analogy breaks down, as in Gloriani's improbable transformation, it should remind us that "the novel," as James wrote in a preface, "appear[s] more true to its character in proportion as it strains, or tends to burst, with a latent extravagance, its mould" ( $A N$ 46). Gloriani, for his part, breaks the mold of the sculptor to become the consummate relational artist: with "his long career behind him and his honours and rewards all round," he turns his attention from object-making to social orchestration, relying on "deep human expertness," the source of his ambiguous power in the late fictions, to establish the ground for interaction, exchange, dialogue, and even irrepressible outburst (NO2 149).

Still, like any relational artist, he cannot control how relations will grow beyond his fertile garden. This is because, as James contends in the preface to Roderick Hudson, relations themselves have agency: "Really, universally, relations stop nowhere, and the exquisite problem of the artist is eternally but to draw, by a geometry of his own, the circle within which they shall happily appear to do so" (AN 5). This contention, as readers of James have noted, includes a redolent ambiguity: Does "to do so" mean "to stop" or "to stop nowhere"? Does the "circle" encapsulate "relations" or "happily" reveal that they are infinitely extended? While James, of course, is analogizing the act of drawing to his own writing practice, his remark, ambiguity included, pertains equally well to the intellectual practice of Fredric Jameson. For what has Jameson given us, over the course of his brilliant career, if not a truly original analytic-“a geometry of his own"-for apprehending social and cultural relations? And what is the engine of this analytic if not the Jamesian ambiguity reappearing as a dialectic of encapsulation and extension? Jameson's concept of postmodernism, for example, forms a theoretical "circle" of enormous circumference that seems, simultaneously, to contain all that defines a given historical period as a period and to be shot through with relations from both the past (residues of the modern and the ancient) and the future (emergent cultural forms and utopian imaginings). This dialectic, moreover, appears as a stylistic phenomenon in his exuberant, capacious, all but endless lists of cultural data:

The enumeration of what follows, then, at once becomes empirical, chaotic, and heterogeneous: Andy Warhol and pop art, but also photorealism, and beyond it, the "new expressionism"; the moment, in music, of John Cage, but also the synthesis of classical and "popular" styles found in composers 
like Phil Glass and Terry Riley, and also punk and new wave rock” ... or, as he puts it more concisely, “etc., etc.” (PO 1)

If, by James's light, this list looks like an effort to track relations that stop nowhere, then it should register as Jameson's own version of "surface reading" (Best and Marcus 1) and "thin description" (Love 401)—that is, as a kind of analytical parataxis that resists the thrust of depth hermeneutics and heroic interpretation. In the recent, lively debate about interpretive method, Jameson's work has been understood to epitomize the latter, but there is a countervailing force in his critical practice: an effort to observe and to describe, to notice surface phenomena and to trace connections between both proximate and disparate entities, ultimately to construct vast associational networks of culture that hang together in the force field of his intelligence and through the swell of his prose. Jameson, in this sense, assumes the vocation of the relational artist as James imagines it in the preface to Roderick Hudson. And by appreciating this vocation, we might finally be able to recast the theorist as an ally - the ally that he has always been-in the newly urgent project to rethink interpretive method.

\section{NOTES}

${ }^{1}$ Ever since F. O. Matthiessen published "James and the Plastic Arts" in 1943, critics have been perennially interested in James's engagement with the fine arts, especially painting. See the special issue of the Henry James Review devoted to "Jamesian Arts," as well as books by Brooks, Griffin, Johnson, Kenner, Tintner, Hopkins, and Winner. On James's engagement with sculpture, in particular, see Bell, Rowe, and Teahan. In addition, Freedman provides the central account of the novelist's career-long interaction with British aestheticism.

${ }^{2}$ For a thorough discussion of the life/death mask, see Cutting.

${ }^{3}$ In The Political Unconscious, Jameson notes "the remarkable transformation of Henry James from minor nineteenth-century man of letters into the greatest American novelist of the 1950s" (221-22). On the category of the great American novel, for which James himself coined the acronym "G. A. N.," see Buell.

${ }^{4}$ For a recent account of James's treatment of media and mediation as problems in their own right, see Goble.

${ }^{5}$ Here Jameson echoes McGurl, who himself echoes Kenner, in suggesting that James competed for prestige with practitioners of other arts in what Bourdieu terms "the game of culture" (12).

${ }^{6}$ On Pygmalion, see Hersey; on the literary treatment of thing/person ambiguity, see Brown.

7The term "panaesthetic" comes from Albright. In this account of Story, James echoes his 1876 account of sculptor Paul DuBois. "[He] is certainly a sculptor," James wrote in the Nation, "and sees things as a sculptor-sees lines and forms and contours, and not intentions, motives, and dramatic effects" (PD 397).

${ }^{8}$ For a fuller analysis of this ambiguity, see Rowe. Also see James's short story "The Tree of Knowledge" (1900), which can be read as a send-up of Story's practice (CS3 220-34).

${ }^{9}$ Edel (vols. 1 and 2), has documented this time in James's life; also see Martin and Person.

${ }^{10}$ In this sense, James's understanding of sculpture is consistent with his life-long interest in performance, drama, and theater; see Kurnick for a recent account of this interest.

${ }^{11}$ For a critical account of relational art, see Bishop. And for an analysis of relational art as part of a wider "social turn" within contemporary aesthetics, see Jackson.

${ }^{12}$ See Edel (vol. 5), for an account of the publication histories of both texts.

${ }^{13}$ The best representation of James's early response to nascent modernism can be found in Parisian Sketches: Letters to the New York Tribune, 1875-1876. It was in Whistler's garden where James heard the anecdote that became the "germ" for The Ambassadors (NB 140). Still, even though James at first rejected nascent modernism, he did not unequivocally embrace the neoclassicism of nineteenth-century sculpture; see, for instance, Danto.

${ }^{14}$ James's correspondence with Andersen has been published as Beloved Boy: Letters to Hendrik C. Andersen, 1899-1915. For a thorough account of their relationship, see the two introductions to that volume. ${ }^{15}$ For the full history of Arch, see Folpe.

${ }^{16} \mathrm{On}$ the material practices of sculpture, see Genette, Goodman, and Hosmer. On American sculptors in nineteenth-century Rome, see Crane, Gerdts, and Kasson.

${ }^{17}$ In this sense, the Arch exemplifies "the logic of the monument" as Krauss has defined it (34). 
WORKS BY HENRY JAMES

AN-The Art of the Novel: Critical Prefaces by Henry James. Chicago: U of Chicago P, 2011. Print.

Beloved Boy: Letters to Hendrik C. Andersen, 1899-1915. Ed. Rosella Mamoli Zorzi. Charlottesville: U of Virginia P, 2004. Print.

CL-The Complete Letters of Henry James, 1872-1876. Ed. Pierre A. Walker and Greg W. Zacharias. Vol. 1. Lincoln: U of Nebraska P, 2008. Print.

CS1-Complete Stories, 1874-1884. New York: Library of America, 1999. Print.

CS2_Complete Stories, 1884-1891. New York: Library of America, 1999. Print.

CS3-Complete Stories, 1898-1910. New York: Library of America, 1996. Print.

CTW-Collected Travel Writings: The Continent. New York: Library of America, 1993. Print.

HJC_-"The Sculpture of Fredrick MacMonnies.” Henry James Compositions (MS Am 1237.7). Houghton Library, Harvard U.

HJL-Henry James Letters. Ed. Leon Edel. Vol. 4. Cambridge: Belknap P of Harvard UP, 1984. Print.

NB-The Complete Notebooks of Henry James. Ed. Leon Edel and Lyall H. Powers. New York: Oxford UP, 1987. Print.

NO1-Novels, 1871-1880. New York: Library of America, 1983. Print.

NO2-Novels, 1903-1911. New York: Library of America, 2010. Print.

Parisian Sketches: Letters to the New York Tribune, 1875-1876. Ed. Leon Edel and Ilse Dusoir Lind. New York: NYUP, 1957. Print.

PE-The Painter's Eye: Notes and Essays on the Pictorial Arts. Ed. John L. Sweeney. Madison: U of Wisconsin P, 1989. Print.

PD-Unsigned Note, comment on Paul DuBois. Nation 22 (22 June 1876): 397-98.

WWS-William Wetmore Story and His Friends. Vol. 2. Edinburgh: Blackwood, 1903. Print.

\section{WORKS BY FREDRIC JAMESON}

The Antinomies of Realism. London: Verso, 2013. Print.

Marxism and Form. Princeton: Princeton UP, 1971. Print.

The Modernist Papers. London: Verso, 2007. Print.

The Political Unconscious: Narrative as a Socially Symbolic Act. Ithaca: Cornell UP, 1981. Print.

PO-Postmodernism, or, The Cultural Logic of Late Capitalism. Durham: Duke UP, 1991. Print.

\section{OTHER WORKS CITED}

Albright, Daniel. Panaesthetics: On the Unity and Diversity of the Arts. New Haven: Yale UP, 2014. Print. Bell, Millicent. "James and the Sculptor." Yale Review 90.4 (2002): 18-47. Print.

Best, Stephen, and Sharon Marcus. "Surface Reading: An Introduction." Representations 108.1 (2009): 1-21. Print.

Bishop, Claire. "Antagonism and Relational Aesthetics." October 110 (2004): 51-79. Print.

Bourdieu, Pierre. Distinction: A Social Critique of the Judgment of Taste. Trans. Richard Nice. Cambridge: Harvard UP, 1984. Print.

Bourriaud, Nicholas. Relational Aesthetics. Trans. Simon Pleasance et al. Paris: Les Presse du Réel, 1998. Print. Brooks, Peter. Henry James Goes to Paris. Princeton: Princeton UP, 2007. Print.

Brown, Bill. A Sense of Things: The Object Matter of American Literature. Chicago: U of Chicago P, 2003. Print.

Buell, Lawrence. The Dream of the Great American Novel. Cambridge: Belknap P of Harvard UP, 2014. Print.

Cameron, Sharon. Thinking in Henry James. Chicago: U of Chicago P, 1989. Print.

Crane, Sylvia E. White Silence: Greenough, Powers, and Crawford: American Sculptors in NineteenthCentury Italy. Coral Gables: Florida U of Miami P, 1972. Print.

Cutting, Andrew. Death in Henry James. Basingstoke: Palgrave Macmillan, 2005. Print.

Danto, Arthur Coleman. "The Future of the Madonna." Henry James Review 19.2 (1998): 113-25. Print.

Edel, Leon. Henry James. 5 vols. Philadelphia: Lippincott, 1953-72. Print.

Evans, Brad. "Relating in Henry James (The Artwork of Networks)." Henry James Review 36.1 (2015): 1-23. Print.

Felski, Rita. “'Context Stinks!” New Literary History 42.4 (2011): 573-91. Print.

Folpe, Emily Kies. It Happened on Washington Square. Baltimore: Johns Hopkins UP, 2002. Print.

Freedman, Jonathan. Professions of Taste: Henry James, British Aestheticism, and Commodity Culture. Stanford: Stanford UP, 1993. Print.

Fried, Michael. Art and Objecthood. Chicago: U of Chicago P, 1998. Print.

Genette, Gérard. The Work of Art: Immanence and Transcendence. Trans. G. M. Goshgarian. Ithaca: Cornell UP, 1997. Print.

Gerdts, William. American Neo-Classical Sculpture. New York: Viking, 1973. Print.

Goble, Mark. Beautiful Circuits: Modernism and Mediated Life. New York: Columbia UP, 2010. Print. 
Goodman, Nelson. Languages of Art: An Approach to a Theory of Symbols. Indianapolis: Hackett, 1976. Print.

Griffin, Susan. The Historical Eye: The Texture of the Visual in Late James. Boston: Northeastern UP, 1991. Print.

Hawthorne, Nathaniel. Novels. New York: Library of America, 1983. Print.

Hersey, George. Falling in Love with Statues: Artificial Humans from Pygmalion to the Present. Chicago: U of Chicago P, 2006. Print.

Hopkins, Viola. "Gloriani and the Tides of Taste." Nineteenth-Century Fiction 18.1 (1963): 65-71. Print. Hosmer, Harriett. “The Process of Sculpture.” Atlantic Monthly 14 (Dec. 1864): 734-38. Print.

Jackson, Shannon. Social Works: Performing Art, Supporting Publics. New York: Routledge, 2011. Print. "Jamesian Arts." Special issue of the Henry James Review 23 (2002). Print.

Johnson, Kendall. Henry James and the Visual. Cambridge: Cambridge UP, 2007. Print.

Kasson, Joy. Marble Queens and Captives: Women in Nineteenth-Century American Sculpture. New Haven: Yale UP, 1990. Print.

Kenner, Hugh. The Pound Era. Berkeley: U of California P, 1971. Print.

Krauss, Rosalind. "Sculpture in the Expanded Field." October 8 (1979): 30-44. Print.

Kurnick, David. Empty Houses: Theatrical Failure and the Novel. Princeton: Princeton UP, 2013. Print.

Love, Heather. "Close but not Deep: Literary Ethics and the Descriptive Turn." New Literary History 41.2 (2010): 371-91. Print.

Martin, Robert K., and Leland S. Person, eds. Roman Holidays: American Writers and Artists in NineteenthCentury Italy. Iowa City: U of Iowa P, 2005. Print.

McGurl, Mark. The Novel Art: Elevations of Fiction after Henry James. Princeton: Princeton UP, 2001. Print.

Posnock, Ross. The Trial of Curiosity: Henry James, William James, and the Challenge of Modernity. New York: Oxford UP, 1991. Print.

Rowe, John Carlos. "Hawthorne’s Ghost in Henry James’s Italy: Sculptural Form, Romantic Narrative, and the Function of Sexuality." Henry James Review 20.2 (1999): 107-34. Print.

Stevens, Wallace. The Necessary Angel: Essays on Reality and the Imagination. New York: Vintage, 1951. Print.

Teahan, Sheila. "My Sculptor/My Self: A Story of Reading.” Henry James Review 23.2 (2002): 246-54. Print.

Tintner, Adeline R. The Museum World of Henry James. Ann Arbor: UMI, 1986. Print.

Winner, Viola Hopkins. Henry James and the Visual Arts. Charlottesville: UP, 1970. Print. 